\title{
Evaluation of Efficacy of Washing Treatment for Extending the Post-Harvest Life of Tomato (Solanum lycopersicum L)
}

\author{
D.M.C. Champathi Gunathilake and Ashwini K. Tiwari* \\ College of Agriculture, Fisheries and Forestry, Fiji National University, Fiji \\ *Corresponding author
}

\begin{tabular}{|c|c|}
\hline \multicolumn{2}{|r|}{ A B S T R A C T } \\
\hline & \multirow{6}{*}{$\begin{array}{l}\text { Tomato is consider as a vegetable and or fruits. However, mostly tomato considered as } \\
\text { vegetable. Tomato is one of the most intensive consuming vegetable/fruits crop in all over } \\
\text { the world. About } 25 \% \text { - } 40 \% \text { of post-production losses of tomato can be observed specially } \\
\text { in developing countries. These losses are mainly occurred during post-harvest operations } \\
\text { such as harvesting, packing, storage and transportation. As well as product hygiene is very } \\
\text { important in order to extend its shelf-life. Washing of fruit crops after harvesting is one of } \\
\text { the main important post-harvest operations which directly affected to improve the shelf- } \\
\text { life product. This study was conduct to evaluate the product call BiOWiSH }{ }^{\mathrm{TM}} \text { (BW) used } \\
\text { as washing powder and sanitizer in order to extend the shelf life and hygienic condition of } \\
\text { fruits and vegetables. BW washing treatment was compared with existing washing } \\
\text { treatment by weight loss percentage, visual quality rating (VQR), firmness, total soluble } \\
\text { solids (TSS), pH change and colour change, to evaluate BW treatment effect. Results } \\
\text { revealed that BW treatment was not shown significant effect to extend post-harvest shelf- } \\
\text { life of tomato in comparison to existing washing treatment. }\end{array}$} \\
\hline & \\
\hline & \\
\hline Article Info & \\
\hline $\begin{array}{l}\text { Accepted: } \\
17 \text { September } 201 \\
\text { Available Online: } \\
10 \text { November } 201\end{array}$ & \\
\hline & \\
\hline
\end{tabular}

\section{Introduction}

Tomato is one of the most intensive grown crop in all regions of the world. Total world production of tomato was 152.9 million ton with a value $\$ 74.1$ billion in year 2009 (FAOSTAT Database, 2009). World largest tomato producer is China. The top 5 largest tomato producing countries are China, India, United States and Turkey. They account for $70 \%$ of global tomato production (www.hortibiz.com). About 30\% - 40\% of post-production losses of these fruits and vegetables are observed specially in developing countries. These losses occur mainly during harvesting and post-harvest operations such as handling, packing, storage, transportation, and marketing (Ryall and
Lipton, 1972). After harvesting tomato starts deterioration mainly due to high respiration because of high water content and perishable in nature. In addition, stored environment condition caused to increase postharvest diseases and reduce shelf life. Shelf life of the tomato can be increased providing suitable low temperature $\left(15^{\circ} \mathrm{C}\right)$ and increasing product hygiene (Anon 1986). Cleaning and washing are very important practices in order to improve the hygienic condition of product. That has greatly affected to improve postharvest life of tomato. Soaking and rinsing or spray washing are generally followed washing methods of fruits and vegetables. Proper sanitation of the washing water is essential to 
maintain to prevent spread of diseases and inoculums build up in the wash water. The most commonly used sanitizer to wash fruits and vegetable is chlorine (100-150 ppm) solution. $\mathrm{BiOWiSH}^{\mathrm{TM}}(\mathrm{BW})$ is a powdered product introduced for washing fruits and vegetables as a sanitizer. BW producers revealed $\mathrm{BW}$ is a powerful composite biocatalyst that breaks down complex organic molecules, eliminating waste and odours, increases storage life by maintaining the freshness, and reduces harmful chemicals used for washing. Hence, this research study was conducted for determination the efficacy of BW solution to extend the shelf-life of tomato in comparison to existing washing treatment

\section{Materials and Methods}

Experiment was conducted at Institute of Post-Harvest Technology, Sri Lanka. Tomato harvested at correct stage of maturity used for this experiment. Washing solution was prepared by $5 \mathrm{~g}$ of $\mathrm{BW}$ powder in one litre of water. Experimental tomato sample (1000g) was dipped 10min in this solution washed and remove excess solution viper out by assonant tissue paper. As a control same amount of tomato sample was dipped in chlorinated (100-150 ppm) water washed and remove excess water viper out by assonant tissue paper. Those samples were placed at laboratory in room temperature with proper ventilation. Weight loss percentage, visual quality rating (VQR), firmness change, total soluble solids (TSS)change, $\mathrm{pH}$ change and colour change were analysed by adopting following procedures and instruments. These parameters were used for determination shelflife extension of tomato. All experiments were replicate 3 times

\section{Analysis of weight loss percentage}

The physiological weight loss of tomato was determined using formula 2. Weight of the tomato samples were measured at regular 2 days intervals for 9 days (experimental duration).

\section{Visual Quality Rating (Visual quality changers) (VQR) \\ Weight loss $\%=\frac{\text { Final weight of the sample }}{\text { Initial weight of the sample }} \times 100 \quad-$ Formula 2.1}

Visual Quality Rating (VQR) was determined by observations of tomato samples at regular 2 days interval for nine days. Individual tomato fruits in sample were evaluated and rated using table 1 .

\section{Firmness change}

The firmness of tomato was measured 2days intervals for 9 days. Digital fruit firmness tester with a $4 \mathrm{~mm}$ cylindrical shape (flat end) probe (TR Model 53205) was used.

\section{Total soluble solids (TSS) change}

The total soluble solids (TSS) in fruit juice was recorded using a hand held refractometer (ATAGO, model: HR-5) and reading was reported as percentage of brix. Procedure explain by Sultani et al., (2010) was adopted to analysis TSS that $10 \mathrm{~g}$ piece was taken from samples and blended for one minute in $50 \mathrm{ml}$ of distilled water and measured for TSS.

\section{pH change}

$\mathrm{pH}$ of experimental tomato samples were measured in two days interval for 9 days using a digital $\mathrm{pH}$ meter.

\section{Colour change}

Outerpeel colour of tomato samples were measured 2 day regular intervals for 9 days using mini-scan XE plus Hunter Lab Colorimeter. $\mathrm{L}^{*}, \mathrm{a}^{*}, \mathrm{~b}^{*}$ values were determined. $\mathrm{L}^{*}, \mathrm{a}^{*}, \mathrm{~b}^{*}$ values were 
determined. $L^{*}$ stood for lightness (back $=0$, white $=100), a^{*}$ represented for greenness and redness ( $+a^{*}$, redness; $-a^{*}$; greenness), $b^{*}$ indicated blueness and yellowness $\left(-b^{*}\right.$, blueness; $+b^{*}$, yellowness)

\section{Statistical analysis}

Experimental data was analysed by SAS ${ }^{\circledR}$ computer statistical package. Each treatments were replicated three times. Analysis of Variance (ANOVA) on Complete Randomized Design (CRD) by General Liner Model (GLM) procedure was performed. Treatment mean were separated by Duncan Multiple Range Test.

\section{Results and Discussion}

\section{Change of weight loss percentage}

Weight loss of tomato occurs mainly due to continuous evapotranspiration of moisture from fruits. Figure 1 shows the change of weight loss of BW treated tomato and control samples. Results clearly indicated that BW treatment was not significant effected to change weight loss of tomato in comparison to control. BW treatment was unable to control water evaporation from tomato

\section{Change of VQR of tomato}

The visual quality of fresh tomato is one of the most important factor for determination market value. VQR was determined by trained panel. BW treated tomatoes were kept unchanged for until 2 days however, control sample start deteriorate from its first day. After the 2 day BW treated samples were also start deteriorate similar way as shown in figure 2. It was clear from the results that BW treatment was not shown any significant effect to improve visual quality of tomato

\section{Change of firmness of tomato}

Figure 3 shows the firmness change of experimental tomato samples. Results reveiled that BW tretmant was not sinificanlty effected to alter its firmness. Wills et al., (1980) showed that firmness of fruits and vegetables was reduced with starting of repining process. The $\mathrm{BW}$ treated was not reported significantly effect in comparison to control.

Table.1 Rating scale for overall Visual Quality of Produce (VQR)

\begin{tabular}{|c|c|c|}
\hline Score & Degree of severity & Description \\
\hline 9 & Excellent & Essentially no symptoms of deterioration \\
\hline 7 & Good & Minor symptoms of deterioration, not objectionable \\
\hline 5 & Fair & $\begin{array}{l}\text { Deterioration evident, but not serious, limit of sale } \\
\text { ability }\end{array}$ \\
\hline 3 & Poor & Serious deterioration, limit of usability \\
\hline 1 & Extremely poor & Not usable \\
\hline
\end{tabular}

Table.2 Mean comparison between BW treatment and control

\begin{tabular}{|l|c|c|c|c|c|c|c|c|}
\hline Treatment & $\begin{array}{l}\text { Weight } \\
\text { Loss\% }\end{array}$ & VQR & $\begin{array}{c}\text { Firmn } \\
\text { ess }\end{array}$ & TSS & pH & \multicolumn{4}{|c|}{ Colour change } \\
\hline BW & $3.185^{\mathrm{a}}$ & $6.3^{\mathrm{a}}$ & $23.56^{\mathrm{a}}$ & $3.68^{\mathrm{a}}$ & $4.27^{\mathrm{a}}$ & $53.34^{\mathrm{a}}$ & $11.77^{\mathrm{a}}$ & $35.81^{\mathrm{a}}$ \\
\hline Con & $3.083^{\mathrm{a}}$ & $5.7^{\mathrm{a}}$ & $24.20^{\mathrm{a}}$ & $3.64^{\mathrm{a}}$ & $4.33^{\mathrm{a}}$ & $52.80^{\mathrm{a}}$ & $12.01^{\mathrm{a}}$ & $33.79^{\mathrm{a}}$ \\
\hline
\end{tabular}

* Columns having same letter are not significantly difference at $\alpha=0.05$ by DMRT 
Fig.1 Change of weight loss percentage of tomato in experimental samples

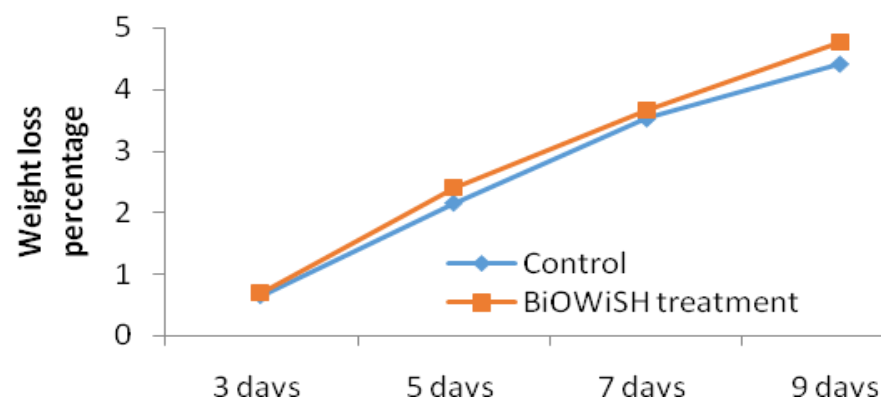

Fig.2 Change of VQR of banana in experimental sample

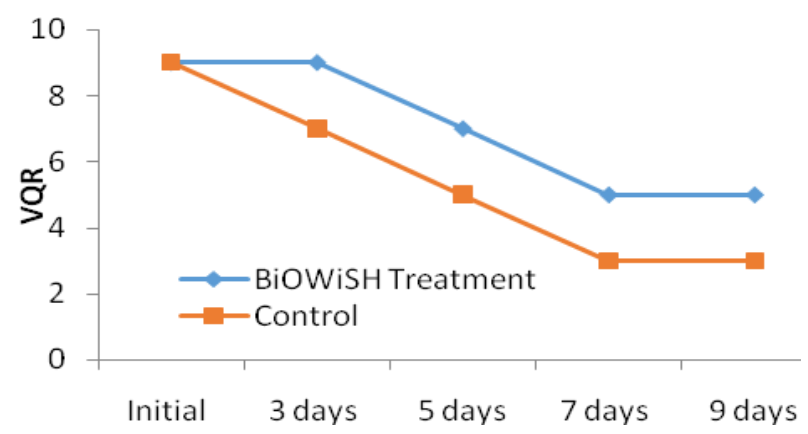

Fig.3 Change of firmness of tomato in experimental samples

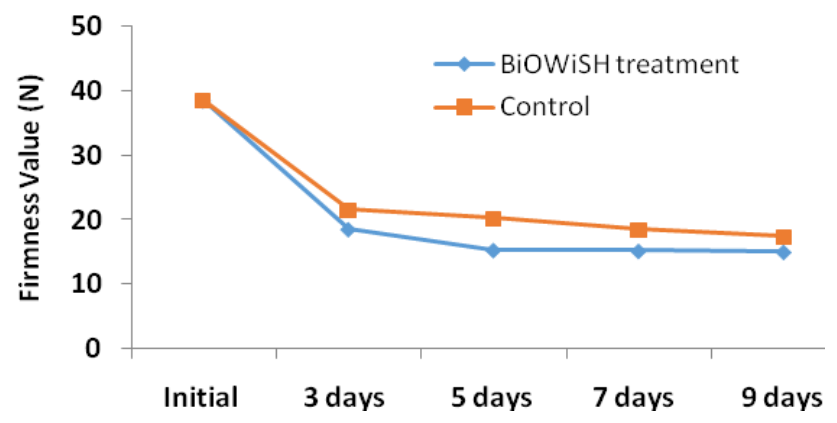

Fig.4 Change of TSS (bricks) of tomato in experimental samples

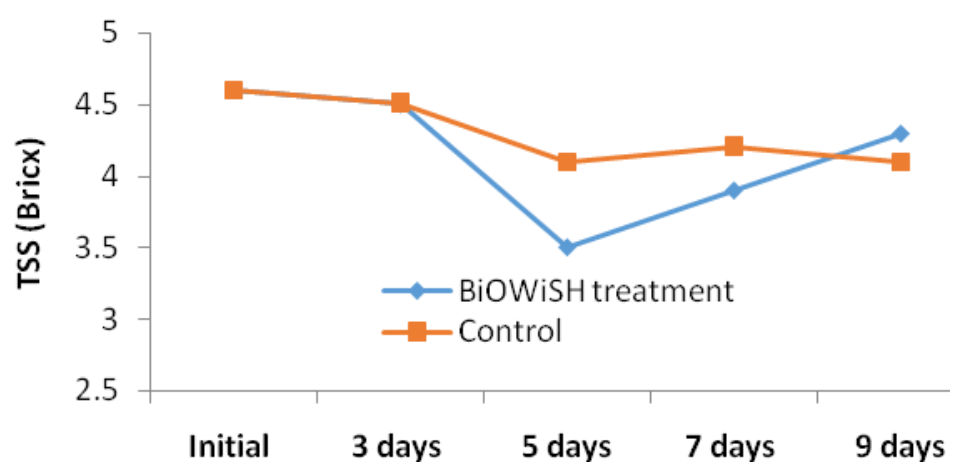


Fig.5 Change of $\mathrm{pH}$ (acidity) of tomato in experimental samples

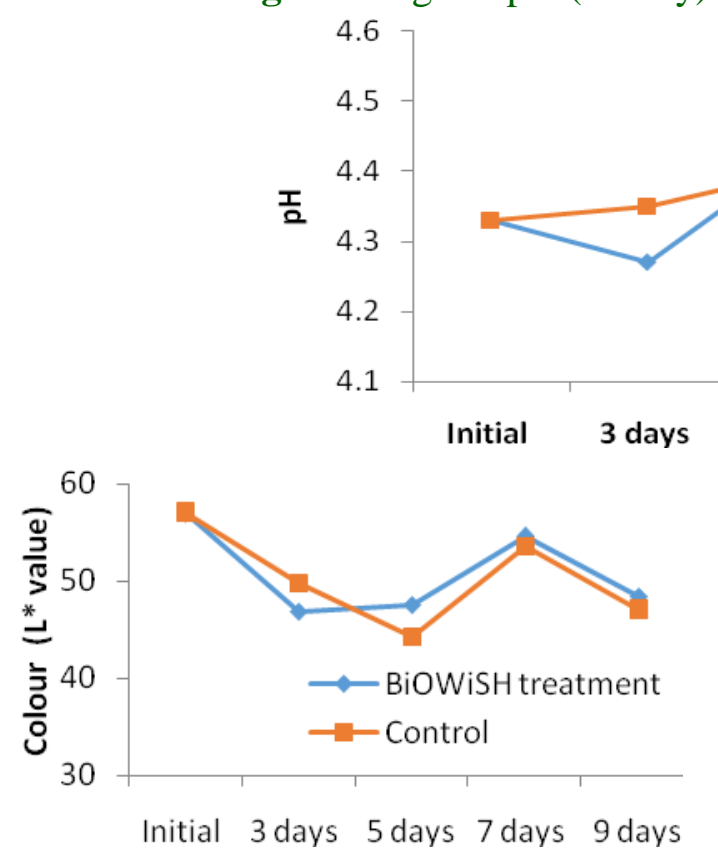

Fig.6 Change of L colour value

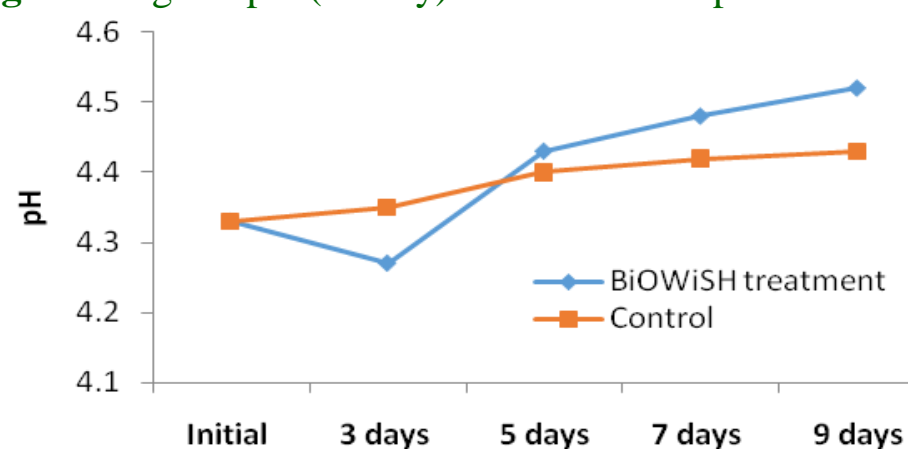

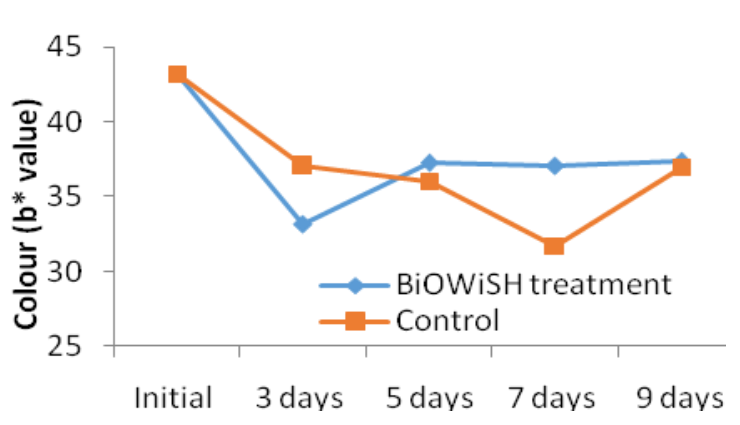

Fig.8 Change of b colour value

\section{Change of TSS of experimental tomato samples with time}

Figure 4 shows change of Total Soluble Solids (TSS) of experimental samples. Ryall and Lipton (1972) indicate TSS is increased with ripening, if the ripening process was slow, TSS change was also slow. BW treated samples were not shown significant different in comparison to control samples for TSS change.

\section{Change of acidity (pH)}

Figure 5 shows change of acidity $(\mathrm{pH})$ experimental samples. $\mathrm{pH}$ of fruits changes

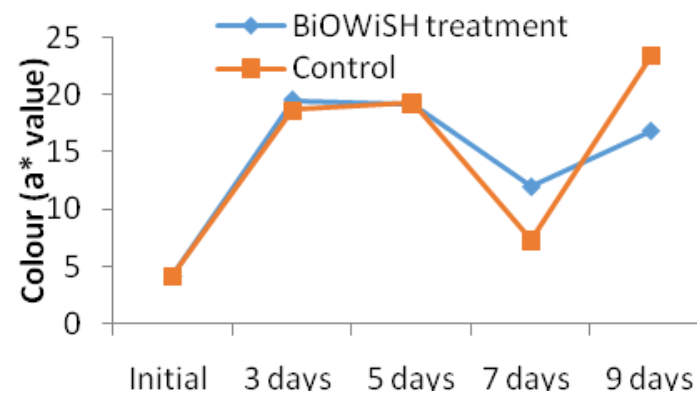

Fig.7 Change of a colour value with maturity(Wills et al., 1980). Tomato were slight low $\mathrm{pH}$ in initially however slight increase in acidic ranger can be observed with time of storage. Although BW treated samples were shown slight decrease in first two days, after that it was increased high rate than control sample. Hence, results revealed that BW treatment had not shown special effect to control $\mathrm{pH}$ level of the fruits.

\section{Change of colour $\left(L^{*} \mathbf{a}^{*} \mathbf{b}^{*}\right.$ values $)$}

Figure 6, 7 and 8 show colour change of the experimental samples with time. It was clear that colour change of $\mathrm{BW}$ treated tomatoes 
were not shown significant difference comparison to control treatment. Hence it can be concluded that BW treatment was not affected to colour change of tomato fruits.

Table 2 is shown the results of the mean comparison by Duncan Multiple Range Test (DMRT). It was clear from the results that BW treatment was not shown significantly effected to extend the post-harvest shelf-life tomato. DMRT was shown clearly, BW treatment was not effected to alter the parameters negotiated tomato shelf-life i.e. weight loss percentage, visual quality rating (VQR),firmness change, total soluble solids (TSS)change, $\mathrm{pH}$ change and colour change comparison to control treatment (existing method)

Based on the overall discussion made over, it can be concluded that BW treatment was not significantly effected to improve shelf life tomato crop. However, BW treatment had been shown ability to control microbiological contamination and spreading, but it was not significant.

\section{References}

Anon, (1986). A Handbook on Shipping Perishable Commodities. American President Lines, Oakland, CA.

Anonymous, (1986). Improvement of postharvest fresh fruits and vegetables handling. Food and Agriculture Organization of United Nations, A manual, Pp 14-32,184-186.

Arvanitoyannis, I.S., Khah, E.M. and Christakou, E.C. (2005). Effect of grafting and MAP on egg-plant quality parameters during storage. J. of Food Science technology.33:324-356.

Gupta, O.P andmetha, N.(1987). Effect of postharvest application of fungicides chemicals and pre cooling treatment's on the shelf life of Galber fruits. Hrayana Agricultural University 561-580 pp.

Karder, A.A.(1993).Modified and control atmosphere storage of tropical fruits. In: post-harvest handling of tropical fruits (Champ, B.R., highly E and Johnson G.I. Eds).ACIAR proceeding 50, 239-249.

Mary L. Duryea(2010), Tomato research reports 2009-2010, University of Florida, $7^{\text {th }}$ September 2010, viewed on 20 August 2017, <www.floridatomatoes.org>

Picha, D.H. (1988). Storage temperature influences for watermelon quality. Louisiana Agricultural University 31: Pp 4-5.

Ryall, M. S A. and Lipton, W.J. 1972.Handling Transportation and storage of Fruits and Vegetables, 1.AVI Publishing, Westport.

Tomato production facts around the world (2017), viewed on 09 September 2017 www.hortibiz.com

Wills, R.B.H, bembridge, P.A, Scott,K.J.(1980).Use of flesh firmness and other objectives Test to determine consumer acceptability of delicious Apple. Aust. $J$ of Exp Agriculture AnimalHusbandry20: 252-256.

\section{How to cite this article:}

Champathi Gunathilake, D.M.C. and Ashwini K. Tiwari. 2017. Evaluation of Efficacy of Washing Treatment for Extending the Post-Harvest Life of Tomato (Solanum lycopersicum L). Int.J.Curr.Microbiol.App.Sci. 6(11): 1999-2004. doi: https://doi.org/10.20546/ijcmas.2017.611.238 